\title{
トビイロウンカの翅型決定に関する密度効果の分析 ${ }^{1}$
}

\author{
城野晋
}

京都大学農学部昆虫学研究室

はじめに

バッタ, ヨトウガ, チャタテムシ, ナナフシ, ヨツモ ンマメゾウムシ，アブラムシなどには相変異あるいはそ れに似た多型現象が見られるが，これらに類似の現象が 稲作の重要害虫であるウンカ類にも存在している。すな わち長翅型, 短翅型の 2 型が存在している。その出現機 構に関しては従来いくつかの研究が行なわれており，末 永（1950） は寄主植物であるイネの生化学的性質の如何 により大きく影響されるとし，三宅ら (1951，1953） は 生息密度, 食物の質, 日長などが関係していると述べて いる。また岸本 $(1956,1956 \mathrm{a})$ は密度, 食物の萎调度, 環境の生物学的条件ずけなどの影響していることを認め た。

著者はトビイロウンカ Nilaparvata lugens STÅL に ついてこれらの諸要因中から密度要因を取りあげ, 密度 効果の内容のいくつかを分析しまた雌雄による翅型決定 に相違点の認められることを示した。

本交に入るに先だち御指導頂いた内田俊郎教授, 河野 達郎助教授並びに種々御援助下さった㦑俊一氏はじめ京 都大学農学部昆虫学研究室の諸氏に深く感謝する。

\section{材 料 と方 法}

農林省四国農試岸本良一氏より送られたトビイロウン カ卵より孵化した幼虫をひきつづき累代飼育した。飼育 は口径 $1.8 \mathrm{~cm}$, 深さ $18 \mathrm{~cm}$ の試験管を用い，これを 横 5 本，縦 12 本並ぶ試験管立てに横に一列おきに並 ベ, 特にことわらぬ限り $27.5^{\circ} \mathrm{C}, 16$ 時間日長に調節さ れた恒温室内で行なった。飼料としては主としてイネの 芽出し苗の 12〜3 cm になったものを利用し，萎调しな いうちに適時試験管共取り換えた。

結果と考察

\section{密度奻果は成虫によっても起こされるか}

本実験では飼料として芽出し苗 1 本を各試験管当りに 供した。第 1 表に示す如く対照の $1 ， 5 ， 10$ 頭区ではそ
れぞれ此長翅型の出現率（早 M率）が 38.9\%，70.0\%， $100 \%$ であるのに対し，卵孚化幼虫 1 頭に成虫 4 頭を集合 させた試験区（1 +4 区）では $9 \mathrm{M}$ 率は 90.8\% であ った。これは全幼虫期間を通し幼虫 5 頭であった対照 区（5頭区）より 20\% ほど％ M 䄳がふえており，密 度効果は同種の成虫によっても得られるものであり，し かもその効果は大であることが示された。

第 1 表 同一種成虫と集合させた場合の趐型

\begin{tabular}{|c|c|c|c|c|c|c|}
\hline 飼育密度 & o $\mathbf{M}$ & 우 $\mathrm{M}$ & 우 $\mathrm{B}$ & $\begin{array}{l}\text { ㅇ } \mathrm{M} \\
(\%)\end{array}$ & $\begin{array}{l}\text { 実験 } \\
\text { 回数 }\end{array}$ & $\begin{array}{l}\text { 死亡率 } \\
(\%)\end{array}$ \\
\hline $\begin{array}{c}1 \\
5 \\
10 \\
1+4 \text { 成虫 }\end{array}$ & $\begin{array}{r}9 \\
16 \\
8 \\
8\end{array}$ & $\begin{array}{r}7 \\
7 \\
10 \\
10\end{array}$ & $\begin{array}{r}13 \\
3 \\
1\end{array}$ & $\begin{array}{r}38.9 \\
70.0 \\
100.0 \\
90.8\end{array}$ & $\begin{array}{r}30 \\
8 \\
5 \\
30\end{array}$ & $\begin{array}{l}10.0 \\
35.0 \\
64.0 \\
36.7\end{array}$ \\
\hline
\end{tabular}

（註） $\mathrm{M}$ ：長翅型 $\mathrm{B}$ ：短翅型

\section{密度効果は種に特有なものか}

この実験では飼料としてイネ（品種美穂錦）の葉を試 験管当り 1 枚用い, ヒメトビウンカ Delphacodes striatella の成虫を共に入れて飼育した。第 2 表に示す如く 対照の 1，5，10，20 頭区ではそれぞれ + $\mathrm{M}$ 率が $6.3 \%$, $2.3 \% ， 22.9 \% ， 46.3 \%$ であったのに対し, トビイロウ ンカ卵孚化幼虫 1 頭にヒメトビウンカ成虫 4 頭を集合させ た試験区（1+4区）では $69.2 \%$ の 早 $\mathrm{M}$ 率を得た。 この場合ヒメトビウンカ成虫のトビイロウンカ孵化幼虫 に与えた密度効果はトビイロウンカ孵化幼虫 20 頭によ るものより大となったわけで, トビイロウンカの長翅型 発現に関与する密度効果は種に特有なものではなく，他 種のしかも成虫によってもひき起こされることが示され た。こういった現象は Husain and MAthur (1936) によりバッタの 1 種 Schistocerca gregaria でも知られ ており，幼虫 1 頭を他の非移動性バッタ Poecilocerus pictusなどと集合させると，群集相の体色を示すに至る という。

\section{密度の感受方法としての相互刺㦸}

翅型決定に及ぼす密度効果を考えた場合，幼虫相互間

1 京都大学農学部昆虫学研究室業績, 第 365 号 (1963 年 1 月 5 日受領) 
第 2 表 ヒメトビウンカ成虫と集合させた場合の翅型

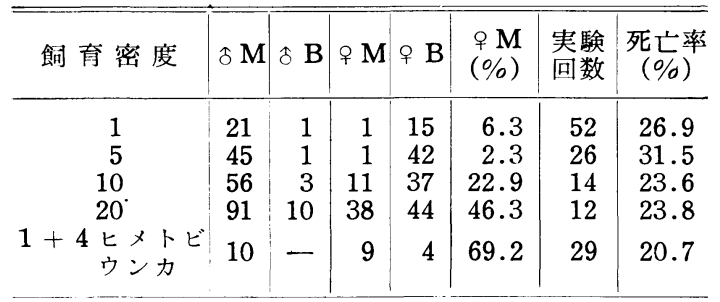

における直接的な相互刺戟, 虫数の増加に伴なう虫 1 頭 当りの摂食量の不足, 高密度によりもたらされる食物の 質的変化, 排泄物などの蓄積による環境の条件ずけなど といった局面が含まれていると思われる。ここではこみ あいによる幼虫相互間の直接的な相互刺戟の翅型决定に 及ぼす影響を実験的に調查した。試験区として卵化後 3 日目から毎日 1 日のうち一定時間（ 7 時間及び 12 時間） のみ径 $7 \mathrm{~mm}$ ，長さ $8 \mathrm{~cm}$ のチーブ内で食飭なしで 30 頭ずつ集合させ，その後は各試験管での 1 頭飼育とし た。集合中は幼虫は飢餓の状態に置かれているわけであ るから，この部分的な飢餓による影響が出てくるかも知 れないので, 対照区としてこの間 1 頭で無給餌の状態に 置く区もあわせ設けた。なお乾燥するのをさけるため, 各チューブに水をしみこませた綿を入れておいた。食慨 は芽出し苗を各試験管当り 3 本とした。これは以下の各 実験でも同様である。

第 3 表一時的な集合と趐型

\begin{tabular}{c|r|r|r|r|r|r|r}
\hline 飼育密度 & o $\mathbf{M}$ & o $\mathbf{B}$ & क $\mathbf{M}$ & क $\mathbf{B}$ & $\begin{array}{c}\text { \% } \mathbf{M} \\
(\%)\end{array}$ & $\begin{array}{c}\text { 実験 } \\
\text { 回数 }\end{array}$ & $\begin{array}{c}\text { 死亡率 } \\
(\%)\end{array}$ \\
\hline 1 & 20 & - & 3 & 11 & 21.4 & 39 & 12.8 \\
5 & 19 & 3 & - & 22 & 0.0 & 11 & 20.0 \\
10 & 18 & - & 6 & 14 & 30.0 & 5 & 24.0 \\
20 & 30 & 1 & 28 & 5 & 84.8 & 4 & 20.0 \\
30 & 25 & - & 27 & - & 100.0 & 3 & 42.2 \\
$1-\mathrm{A}$ & 16 & - & 4 & 4 & 50.0 & 35 & 31.4 \\
$1-\mathrm{B}$ & 9 & - & 7 & 4 & 63.6 & 34 & 41.2 \\
$30-\mathrm{A}$ & 15 & - & 13 & 6 & 68.4 & 2 & 43.3 \\
$30-\mathrm{B}$ & 20 & - & 15 & 2 & 88.2 & 2 & 38.3 \\
\hline
\end{tabular}

（註） 1-A，1-B： 1 頭飼育で 1 日のうち 7 時間及 び 12 時間無給䬦としたもの。

30-A，30-B： 1 日のうち 7 時間及び 12 時 間のみ 30 頭集合としたもの。

第3 表に示す如く, 対照区として設けた $1 ， 5 ， 10$, 20，30 頭区では $9 \mathrm{M}$ 率はそれぞれ $21.4 \% ， 0.0 \%$, $30.0 \% ， 84.8 \% ， 100 \%$ であったのに対し，試験区の 7 時間 (30-A) および 12 時間 (30-B) 30 頭集合区 で

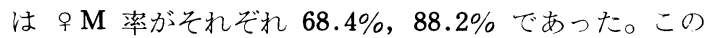
結果からみると翅型決定に及ぼす密度効果として, まず
幼虫相互間の直接的な相互刺戟が大きな役割をはたして いるものと考えられるが，幼虫相互間には何らの直接的 作用関係のない 7 時間 (1-A) 及び 12 時間 (1-B) 無 給餌単独区においても $9 \mathrm{M}$ 率が $50.0 \%, 63.6 \%$ とな っており，幼虫を単に飢餓の状態におくだけでも相当高 率の長翅此を得る事は可能である。しかもその時間を長 くすればするほどその出現率は大となる。このことはト ビイロウンカの翅型決定は高密度による幼虫間の直接的 な相互刺戟だけによるものではなく, 虫数の増加に伴な う提食量の不足といった食物の量的面もある程度の役割 をはたしていることを示すものと思われる。

野田 $(1954,1956)$ によれば，キビクビレアブラムシ Rhopalosiphum prunifoliae では胎生雌より生ずる成 虫は親世代が無翅のときには密度が高くなれば有翅型の 出現率が増加するが,一方孵化後 25 時間以内に飢餓の状 態におかれたものはそうでないものにくらべ有意に有翅 型が増加するようである。しかしアワヨトウ Leucania unipuncta では個体飼京では幼虫体色は緑色ない儿赫褐 色で密度が高くなると顕著な黑化が見られるが，その密 度効果は主として幼虫間の相互刺㦸の程度に応じて現わ れ, 部分的な飢餓などは黒化に関係しない（嚴，1956)。

\section{密度効果と視觉}

視覚による幼虫相互間の諗識が翅型決定にどれほどの 意義を持つかを確かめるため, 明所飼育 (16 時間日長) と暗所飼育（給飭時に数分間光線下にさらした他は全 暗）とを比較調査した。

三宅（1951）によるとトビイロウンカ此の長翅型出現 は管壁のあるなしに拘わらず，虫相互間の距離のみじか いことがその出現の要因となるとし，視觉による相互躵 識の重要性を述べているが，著者の行なった実験では第 4 表に示すように, 우 $\mathrm{M}$ 率は 1，10，30 頭区において 明所飼育ではそれぞれ 25\%，50\%，100\%であり，暗 所飼育ではそれぞれ $0 \% ， 43 \% ， 92 \%$ となっている。す なわち明所飼育でも暗所飼育でも密度依存的に 우 $\mathbf{M}$ 率 が増加している傾向には変化はなく, 視觉による相互の

第 4 表 明所扣よび暗所飼育と翅型

\begin{tabular}{|c|c|c|c|c|c|c|c|c|}
\hline & $\begin{array}{l}\text { 飼育 } \\
\text { 密度 }\end{array}$ & $\delta \mathrm{M}$ & $\delta \mathbf{B}$ & 우 $\mathbf{M}$ & o $\mathrm{B}$ & $\begin{array}{l}\text { ㅇ M } \\
(\%)\end{array}$ & $\begin{array}{l}\text { 実験 } \\
\text { 回数 }\end{array}$ & $\begin{array}{c}\text { 死亡率 } \\
(\%)\end{array}$ \\
\hline $\begin{array}{l}\text { 明所 } \\
\text { 飼育 }\end{array}$ & $\begin{array}{r}1 \\
10 \\
30\end{array}$ & $\begin{array}{l}11 \\
14 \\
23\end{array}$ & $\begin{array}{c}- \\
1 \\
1\end{array}$ & $\begin{array}{r}3 \\
12 \\
19\end{array}$ & $\begin{array}{r}9 \\
12 \\
-\end{array}$ & $\begin{array}{r}25.0 \\
50.0 \\
100.0\end{array}$ & $\begin{array}{r}25 \\
5 \\
3\end{array}$ & $\begin{array}{r}8.0 \\
22.0 \\
52.2\end{array}$ \\
\hline $\begin{array}{l}\text { 暗所 } \\
\text { 飼育 }\end{array}$ & $\begin{array}{r}1 \\
10 \\
30\end{array}$ & $\begin{array}{l}10 \\
12 \\
20\end{array}$ & -1 & $\begin{array}{r}- \\
9 \\
12\end{array}$ & $\begin{array}{r}8 \\
12 \\
1\end{array}$ & $\begin{array}{r}0.0 \\
42.9 \\
92.3\end{array}$ & $\begin{array}{r}25 \\
5 \\
3\end{array}$ & $\begin{array}{l}28.0 \\
32.0 \\
63.3\end{array}$ \\
\hline
\end{tabular}


認職は翅型決定に重要な役割をはたしていないものと思 われる。また篇 (1956) や LoNG (1955) によればアワ ヨトウやウワバの一種 Plusia gamma でも同様の結果 が得られている。

\section{雌雄での翅型決定における相違点}

$27.5^{\circ} \mathrm{C}, 16$ 時間日長で行なわれた上記実験結果から すれば大体に扔いて雌の長翅型が密度の増加と共に増え ていることは明かであり，翅型は密度の影響によって決 定されている。次に雄についてみた場合，これまでの高 温，長日と言う条件下では，どの密度区においても長翅 型が殆んどをしめ，短翅型の出現はまれである。全体で の短型の出現率は $5 \%$ 以内であり，上記条件下で行なっ た 7 回の実験の平均值は $2.2 \%$ であった。そこで温度, 日長の異なる 4 つの実験区をもうけ，各翅型の出現率を 調查した。結果は第 5 表に示す通りであった。

第 5 表 温度・日長と翅型

\begin{tabular}{|c|c|c|c|c|c|c|c|c|c|}
\hline & $\begin{array}{l}\text { 飼育 } \\
\text { 密度 }\end{array}$ & $\delta \mathbf{M}$ & o B & 우 $\mathbf{M}$ & 우 $\mathbf{B}$ & $\begin{array}{l}\stackrel{\circ}{\mathrm{M}} \\
(\%)\end{array}$ & $\begin{array}{l}\text { o B } \\
(\%)\end{array}$ & $\begin{array}{l}\text { 実験 } \\
\text { 回数 }\end{array}$ & $\begin{array}{l}\text { 死亡率 } \\
(\%)\end{array}$ \\
\hline 言日 & $\begin{array}{r}1 \\
5 \\
10 \\
20\end{array}$ & $\begin{array}{l}15 \\
15 \\
10 \\
16\end{array}$ & $\begin{array}{c}-1 \\
1 \\
1\end{array}$ & $\begin{array}{r}1 \\
2 \\
2 \\
16\end{array}$ & $\begin{array}{r}16 \\
23 \\
7 \\
5\end{array}$ & & & $\begin{array}{r}35 \\
10 \\
3 \\
3\end{array}$ & $\begin{array}{r}0.0 \\
20.0 \\
33.3 \\
36.7\end{array}$ \\
\hline 高温 & $\begin{array}{r}1 \\
5 \\
20\end{array}$ & $\begin{array}{l}12 \\
21 \\
15\end{array}$ & $\begin{array}{l}3 \\
7 \\
2\end{array}$ & $\begin{array}{r}-1 \\
17\end{array}$ & $\begin{array}{r}20 \\
16 \\
4\end{array}$ & $\begin{array}{r}0.0 \\
5.9 \\
81.0\end{array}$ & & $\begin{array}{r}40 \\
10 \\
4\end{array}$ & $\begin{array}{l}12.5 \\
10.0 \\
65.0\end{array}$ \\
\hline 低温 & $\begin{array}{r}1 \\
5 \\
20\end{array}$ & $\begin{array}{l}10 \\
12 \\
11\end{array}$ & $\begin{array}{l}3 \\
4 \\
3\end{array}$ & $\begin{array}{r}-\overline{2} \\
11\end{array}$ & $\begin{array}{r}15 \\
16 \\
5\end{array}$ & 68.8 & & $\begin{array}{r}40 \\
8 \\
3\end{array}$ & $\begin{array}{l}25.0 \\
15.0 \\
50.0\end{array}$ \\
\hline E温 & $\begin{array}{r}1 \\
5 \\
20\end{array}$ & $\begin{array}{r}6 \\
18 \\
16\end{array}$ & $\begin{array}{l}5 \\
1 \\
.1\end{array}$ & $\begin{array}{r}2 \\
7 \\
14\end{array}$ & $\begin{array}{r}19 \\
12 \\
6\end{array}$ & & $\begin{array}{l}5 \\
5 .\end{array}$ & $\begin{array}{r}43 \\
10 \\
3\end{array}$ & $\begin{array}{l}25.6 \\
24.0 \\
38.3\end{array}$ \\
\hline
\end{tabular}

（註）高温： $27.5^{\circ} \mathrm{C}$

低温： $20^{\circ} \mathrm{C}$

長日：16 時間日長 短日：8時間日長

雌においてはどの実験区にあっても密度依存的に長翅 型が増加しており, 温度, 日長といった無機的環境要因 は翅型決定に大きな影響を与えていない。ところが雄で は短翅型の出現率は密度との間に明かな関係を示してお らず, 温度, 日長条件と深い関係がみられる。すなわ ち, 高温長日区 では $4.2 \%$, 高温短日区 では $20.0 \%$, 低温長日区では $23.3 \%$ ，低温短日区では $14.9 \%$ であっ た。高温長日区では今までの結果と同じく，雄の短翅型 は出現しにくい。しかし残りの 3 実験区では, 高温長日 区にくらべて相当高率の短翅型雄を得て掞り, 雌の場合 と異なり短日又泜低温において短翅型雄の出現が促進さ れることがわかる。
この点に関して三宅ら（1953）は食飾であるイネの質 的な変化が非常に大きく働いていることを認め, 出穂後 のイネ葉では雄の短翅型が多くなり，また日長もこれに 関与していると述べている。これに対し岸本 (1956a) は雄の短翅の出現にとっては最適密度が存在し， 1 頭区 では出現せず 5 頭区で最もよく出現し, 以下密度の増加 と共汇減少していくことを認め, 更に雄の短翅型出現に とって飼料の新鮮さが保たれることも必要であるとして いる。食飭の質的な影響については分析を欠くが，トビ イロウンカの短翅型注高温長日と言う条件下では全く出 現せ始こともある位で，その出現が非常にまれであるこ とは明らかな事実であり，この点まず第一に注目しなけ ればならない。すなわち雌雄により翅型決定機構はその 様相を異にしており, 雌では密度関係によって大きく左 右されるのに反し雄では温度, 日長といった無機的環境 要因がまず第一義的に作用しているものと思われる。

\section{摘要}

（1）トビイロウンカの雌では，その翅型は幼虫期の 密度効果によって大きく左右されるが, 密度の刺戟効果 は成虫個体に上る刺戟でも，また他種のウンカによる刺 戟でも有効に働らくことが分った。

（2）密度の感受方法としては相互刺戟が長短翅の決 定に大きな役割を果しているがここれがすべてではなく， 部分的な飢餓などを通して働らく食物の量的面も大きい 影響をもっていることが認められた。

（3）視党による相互認傤㹥密度効果にあまり大きな 役割は果していないことが分った。

（4）雌雄により翅型決定はその様相を異にしてお り, 雌では密度効果によりその翅型が大きく影響されて いるのに反し, 雄では高温長日では短翅は殆んど生ぜず 温度, 日長という無機的環境要因によって翅型の発現が 左右されている。

\section{引用文献}

Husain, M. A., and C. B. Mathur (1936) Ind.

J. Agric. Sci. 6: 591 623.

璇 俊一 (1956) 個体群生態学の研究 3: 60 78.

岸本良一（1956）応昆 12: 56～61.

岸本良一 (1956 a ) 応昆 12: 105 111.

Long, D. B. (1955) Trans. R. Ent. Soc. London, 106: $421 \sim 437$.

三宅利雄 - 藤原昭雄 - 石井卓爾 - 乗起 要 (1951) 広島 農試報告 1：1２1． 
三宅利雄 (1951) 応昆 7: 76 .

$$
61 \sim 70 \text {. }
$$

三宅利雄・藤原昭雄（1953）広島県立農試印刷物， pp. NodA, I. (1956) Mem. Ehime Univ. II, B, (3)： $1 \sim 13$. $81 \sim 88$.

NodA, I. (1954) Mem. Ehime Univ. II, B, (1)： 末永 一 (1950) 九州農業研究 7: 61〜62.

\title{
Summary
}

\section{Analysis of the Density Effect as a Determining Factor of the Wing-form in the Brown Planthopper, Nilaparvata lugens}

\author{
By Susumu Јонno
}

Entomological Laboratory, College of Agriculture, Kyoto University, Kyoto

The brown planthopper, Nilaparvata lugens STÅL has two distinct wing-forms, macropterous and brachypterous form, which was proved to be induced by the influence of population density during larval development. Here, the author intended to analyze the mechanism of this density effect upon the wing-form determination.

The stimulus inducing the density effect upon the wing-form determination is not only to be the interaction among larval individuals but that of adult individuals of the same species and even adults of the small brown planthopper, Delphacodes striatella.

The mutual stimulation among individual larvae took some parts in determining the wingform, but it was not the total. The under. feeding during the larval period took another part also. The influence of visual stimulus has no important part in the determination of the wing-form, because percentage of the macropterous female was almost equal with both cases of the rearing under dark or light conditions.

Finally, the difference of the determining factor of the wing-form in both sexes was studied. In female, the brachypterous form was induced largely by the low density. In male, however, it was determined mainly by the climatic factors, such as temperature and day-length. The percentage of the brachpterous? male increased under the condition of short day-length and high temperature and under the low temperature irrespective of day-length. 